\title{
Utilization of poultry droppings in mineral-organic fertilizers
}

\author{
Krystyna Hoffmann, Barbara Lewandowska, Magdalena Borowiec, 'Józef Hoffmann \\ Wroctaw University of Technology, Faculty of Chemistry, Institute of Inorganic Technology and Mineral Fertilizers, \\ ul. Smoluchowskiego 25, 50-371 Wroctaw, Poland \\ ${ }^{1}$ Corresponding author: e-mail: jozef.hoffmann@pwr.wroc.pl
}

The results of physicochemical analyses of raw and composted turkey droppings and those of germination tests carried out using the droppings are presented. On the basis of the results formulas for microelement mineral-organic fertilizers have been developed and fertilizer rates have been determined for winter wheat.

Keywords: composted turkey droppings, mineral-organic fertilizers.

Presented at VII Conference Wasteless Technologies and Waste Management in Chemical Industry and Agriculture, Międzyzdroje, 12 - 15 June, 2007.

\section{INTRODUCTION}

Organic fertilizers are organic substances of various origin used for soil fertilization. They are mostly farm byproducts. Since peat and lignite contain a lot of organic matter they are often added to organic fertilizers. Even though mineral fertilizers' NPK doses are much higher than in the organic fertilizers, organic fertilization is vitally important since the organic fertilizers:

- are a major source of humus in the soil, which increases the latter's sorption capacity;

- improve the soil's structure, its water capacity and aerial properties;

- are a source of nutrients and energy for soil microorganisms;

- alleviate the adverse effect of unbalanced mineral fertilization and strong soil acidity;

-are an important source of microelements.

The use of organic waste substances in fertilizers is beneficial not only for soil fertility but also for waste management.

Because of the increasing concentration of fowls on poultry farms, the removal and management of poultry droppings becomes a major problem. Because of their chemical composition poultry droppings belong to highgrade organic fertilizers (tab. 1). Adult hens produce daily $150-160 \mathrm{~g}$ of droppings, broilers $-65 \mathrm{~g}$, geese $-392 \mathrm{~g}$ and turkeys $-260 \mathrm{~g}$. Besides water, poultry droppings contain large amounts of nitrogen, considerable amounts of phosphorous and several microelements, among others $\mathrm{Cu}, \mathrm{Zn}, \mathrm{Fe}, \mathrm{Co}$ and $\mathrm{Se}$. The agricultural utilization of raw poultry droppings is limited because of their physical properties, consistency and odour. More rational is their prior conversion to compost. The composition and usefulness of such composts depends on their fermentation, the quality of the fertilizer and the type and quantity of additions such as crop residue, food processing industry wastes, sawdust, bark and so on ${ }^{1-3}$.

\section{EXPERIMENTAL}

Physicochemical tests were carried out on adult turkey droppings: raw and after one year of composting. The following were determined: $\mathrm{pH}^{4}$, moisture content by the drier method ${ }^{5}$, organic carbon content by the Tiurin method $^{6}$, potassium content ${ }^{7}$, phosphorous content ${ }^{8}$, calcium content ${ }^{9}$, magnesium content ${ }^{9}$, the total, ammonia and nitrate nitrogen content $\mathbf{t}^{10-12}$.

The test results are shown in table 2 .

The test results shown in the table above indicate that turkey droppings, both raw and composted, contain large quantities of fertilizing components. Further tests were carried out on the composted droppings. In order to determine proper fertilizer rates and the toxic rate for plants, bioassays were performed using the germination test method $^{13}$. Germination tests were carried out in four repetitions. Garden cress was the test plant. The mediumheavy soil free of germination limiting factors was the substrate. The experiments were conducted on Petri dishes 10 in diameter. The substrate was thoroughly mixed with the composted turkey droppings in the amount specified below and wetted with redistilled water. 25 cress seeds were used in the first series, 50 seeds in the second series and the same number of seeds in the third series. The

Table 1. The physicochemical characteristics of poultry droppings ${ }^{3}$

\begin{tabular}{|c|c|c|c|c|c|c|c|}
\hline \multirow{3}{*}{ Poultry species } & \multirow{2}{*}{$\begin{array}{l}\text { Quantity } \\
\text { of droppings from } 1 \text { bird }\end{array}$} & \multirow{2}{*}{$\begin{array}{c}\text { Weight } \\
\text { of } 1 \mathrm{~m}^{3} \\
\text { of droppings }\end{array}$} & \multicolumn{4}{|c|}{ Content in droppings } & \multirow{3}{*}{$\begin{array}{l}\text { Physical form } \\
\text { of droppings }\end{array}$} \\
\hline & & & water & $\mathrm{N}$ & $P$ & $\mathrm{~K}$ & \\
\hline & $\mathrm{g}$ & $\mathrm{kg}$ & wt. \% & wt. \% & wt. \% & wt. \% & \\
\hline Young meat turkeys & 160 & 640 & 70 & 1.76 & 0.69 & 0.40 & loose \\
\hline Young breed turkeys & 231 & 690 & 72 & 1.33 & 0.48 & 0.32 & loose-moist \\
\hline Adult turkeys & 260 & 600 & 64 & 1.68 & 0.61 & 0.38 & loose \\
\hline Commercial laying hens & 150 & 650 & 71 & 1.24 & 0.57 & 0.51 & loose-moist \\
\hline Brood laying hens & 155 & 670 & 73 & 1.31 & 0.68 & 0.59 & loose-moist \\
\hline Adult meat hens & 160 & 680 & 73 & 1.52 & 0.55 & 0.48 & moist \\
\hline Adult geese & 392 & 750 & 82 & 1.38 & 0.58 & 0.43 & moist \\
\hline Adult ducks & 340 & 730 & 80 & 1.00 & 1.40 & 0.62 & moist \\
\hline
\end{tabular}


Table 2. The physicochemical composition determinations for turkey droppings

\begin{tabular}{|c|c|c|c|c|c|}
\hline \multirow{3}{*}{ Characteristic } & \multicolumn{5}{|c|}{ Turkey droppings } \\
\hline & \multirow[b]{2}{*}{ unit } & \multicolumn{2}{|c|}{ raw } & \multicolumn{2}{|c|}{ after one year of composting } \\
\hline & & in sample & $\begin{array}{l}\text { adjusted to dry } \\
\text { matter basis }\end{array}$ & in sample & $\begin{array}{l}\text { adjusted to dry } \\
\text { matter basis }\end{array}$ \\
\hline $\mathrm{pH}$ & & 8.51 & - & 8.76 & - \\
\hline Moisture content & wt. \% & 55.3 & - & 59.2 & - \\
\hline Potassium content & wt. $\%$ of $\mathrm{K}_{2} \mathrm{O}$ & 1.27 & 2.85 & 1.35 & 3.30 \\
\hline Phosphorous content & wt. $\%$ of $\mathrm{P}_{2} \mathrm{O}_{5}$ & 2.04 & 4.56 & 2.73 & 6.69 \\
\hline Calcium content & wt. $\%$ of $\mathrm{CaO}$ & 2.32 & 5.29 & 2.16 & 5.30 \\
\hline Magnesium content & wt. $\%$ of $\mathrm{MgO}$ & 0.46 & 1.04 & 0.54 & 1.33 \\
\hline Total nitrogen content & wt. $\%$ of $\mathrm{N}$ & 1.68 & 3.76 & 2.74 & 6.71 \\
\hline Ammonia nitrogen content & wt. $\%$ of $\mathrm{N}$ & 0.94 & 2.10 & 1.26 & 3.10 \\
\hline Nitrate nitrogen content & wt. $\%$ of $\mathrm{N}$ & 0.0045 & 0.010 & 0.0049 & 0.012 \\
\hline Organic carbon content & wt. $\%$ of $\mathrm{C}$ & 19.22 & 43.00 & 23.09 & 56.59 \\
\hline
\end{tabular}

seeds were distributed on the substrate so that they were not in contact with each other and did not stick to the edge of the dish. The germination capacity was evaluated after 10 days.

The first series objects:

I.1 Reference object - a substratum made of the medium-heavy soil

I.2 The mixed substratum - the medium-heavy soil and the composted turkey droppings at a mass ratio of 3:1 (30 $\mathrm{g}$ soil +10 g droppings)

I.3 The mixed substratum - the medium-heavy soil and the composted turkey droppings at a mass ratio of $4: 1$ (30 g soil +7.5 g droppings)

I.4 The mixed substratum - the medium-heavy soil and the composted turkey droppings at a mass ratio of 5:1 (30 $\mathrm{g}$ soil $+6 \mathrm{~g}$ droppings)

The second series objects:

II.1 The reference object - a substratum made of the medium-heavy soil

II.2 The mixed substratum - the medium-heavy soil and the composted turkey droppings at a ratio of 10:1 (40 g soil +4 g droppings)

II.3 The mixed substratum - the medium-heavy soil and the composted turkey droppings at a ratio of 15:1 (40 g soil +2.7 g droppings)

II.4 The mixed substratum - the medium-heavy soil and the composted turkey droppings at a ratio of 20:1 (40 g soil +2 g droppings)

The third series objects:

III.1 The reference object - a substratum made of the medium-heavy soil

III. 2 The mixed substratum - the medium-heavy soil and the composted turkey droppings at a ratio 50:1 (40 g soil $+0.8 \mathrm{~g}$ droppings)

III.3 The mixed substratum - the medium-heavy soil and the composted turkey droppings at a ratio of 100:1 (40 g soil $+0.4 \mathrm{~g}$ droppings)

III.4 The mixed substratum - the medium-heavy soil and the composted turkey droppings at a ratio of 200:1 (40 g soil $+0.2 \mathrm{~g}$ droppings)

The results of the bioassays are shown in table 3 .

No germinated seeds were found in series I on objects 2, 3 and 4. In series II the poorest germination capacity (relative to the reference object) was observed on objects II. 2 and II.3. A high germination capacity and good plant growth were observed on all the objects of series III. The plants were well rooted and had long and strong stalks.
Table 3. The bioassay results for the turkey droppings composted for one year

\begin{tabular}{|c|r|r|r|r|}
\hline \multirow{2}{*}{$\begin{array}{c}\text { Bioassay series number for } \\
\text { medium-heavy soil and } \\
\text { composted turkey droppings }\end{array}$} & \multicolumn{4}{|c|}{$\begin{array}{c}\text { Germination capacity, \% of } \\
\text { normally germinating seeds }\end{array}$} \\
\cline { 2 - 5 } & \multicolumn{5}{|c|}{ Object No. } \\
\cline { 2 - 5 } & 1 & 2 & 3 & 4 \\
\hline Series I & 92 & 0 & 0 & 0 \\
\hline Series II & 96 & 52 & 60 & 82 \\
\hline Series III & 94 & 98 & 94 & 100 \\
\hline
\end{tabular}

\section{Development of mineral-organic fertilizer compositions}

Compositions of mineral-organic fertilizers for winter wheat were proposed on the basis of the experimental results and literature data ${ }^{\mathbf{1 4}}$. In order to produce 1 ton of wheat grain, one should supply $21 \mathrm{~kg}$ of nitrogen, $4.6 \mathrm{~kg}$ of phosphorous, $15.7 \mathrm{~kg}$ of potassium, $3.3 \mathrm{~kg}$ of calcium, $3.0 \mathrm{~kg}$ of magnesium and $120 \mathrm{~g}$ of manganese, $65 \mathrm{~g}$ of zinc, $14 \mathrm{~g}$ of copper, $12 \mathrm{~g}$ of boron and $1 \mathrm{~g}$ of molybdenum $^{\mathbf{1 4}}$. Nitrogen fertilization increases the protein and gluten levels in grains, which means that the utilization of turkey droppings is advantageous because of their nitrogen content and safe because of the one-year composting time. Figure 1 shows the percentage composition of a mineral-organic fertilizer for winter wheat, based on the composted (for one year) turkey droppings and lignite. The proposed fertilization: up to $4.1 \mathrm{t} / \mathrm{h}$. The respective data for a mineral-organic fertilizer based on the composted (for one year) turkey droppings and earthy peat are shown in fig. 2. The proposed fertilization: up to $2.3 \mathrm{t} / \mathrm{ha}$. The fertilizer compositions were supplemented with microelements in the amounts specified in table 4 .

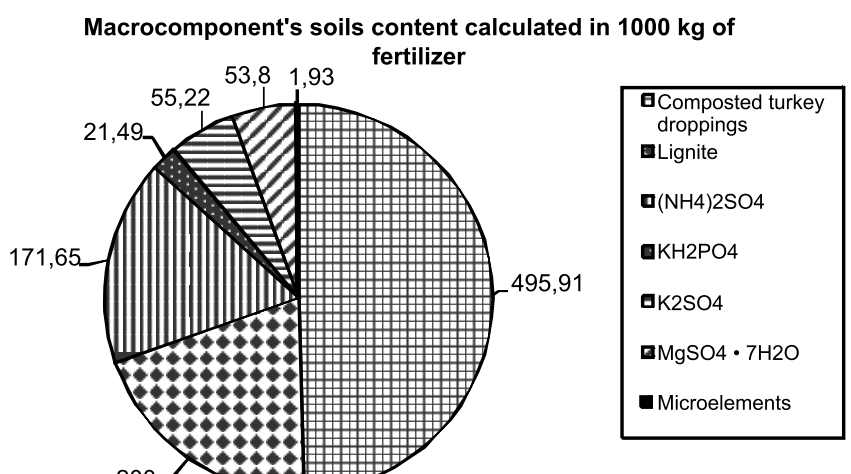

Figure 1. Mass fractions of macrocomponent soils calculated in mineral-organic fertilizer based on composted turkey droppings, lignite and mineral supplements 
Table 4. The microcomponents's soils content calculated in mineral-organic fertilizers based on the turkey droppings composted for one year

\begin{tabular}{|c|c|c|c|c|}
\hline \multirow{2}{*}{ No. } & \multirow{2}{*}{ Chemical compound symbol } & \multirow{2}{*}{ Symbol of introduced microelement } & \multicolumn{2}{|c|}{$\begin{array}{c}\text { Microcomponent's soils content in g/1000 kg of mineral- } \\
\text { organic fertilizer }\end{array}$} \\
\cline { 3 - 5 } & & & $\mathrm{g}$ & $\mathrm{g}$ \\
\cline { 3 - 5 } & & $\mathrm{s}$ & 234 & 195 \\
\hline 1 & $\mathrm{Na}_{2} \mathrm{~B}_{4} \mathrm{O}_{7} \cdot 10 \mathrm{H}_{2} \mathrm{O}$ & $\mathrm{Cu}$ & 139 & 116 \\
\hline 2 & $\mathrm{CuSO}_{4} 5 \mathrm{H}_{2} \mathrm{O}$ & $\mathrm{Mn}$ & 563 & 719 \\
\hline 3 & $\mathrm{MnSO}_{4} \mathrm{H}_{2} \mathrm{O}$ & $\mathrm{Mo}$ & 4 \\
\hline 4 & $\mathrm{Na}_{2} \mathrm{MoO}_{4} \mathrm{H}_{2} \mathrm{O}$ & $\mathrm{Zn}$ & 686 & 572 \\
\hline 5 & $\mathrm{ZnSO}_{4} \cdot 7 \mathrm{H}_{2} \mathrm{O}$ & & & 5 \\
\hline
\end{tabular}

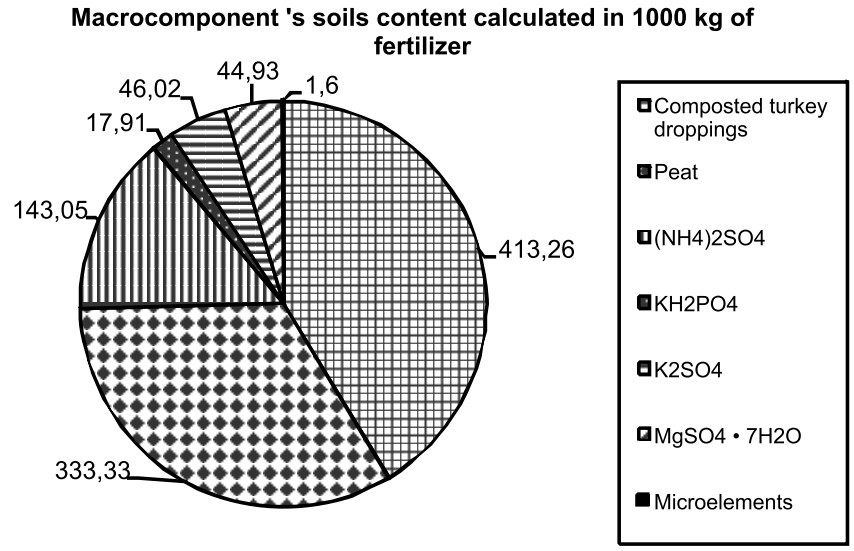

Figure 2. Mass fractions of macrocomponents's soils calculated in mineral-organic fertilizer based on composted turkey droppings, peat and mineral supplements

\section{CONCLUSION}

Poultry droppings are a valuable waste which can be utilized for the production of mineral-organic fertilizers. The developed mineral-organic fertilizer formulas based on turkey droppings, lignite or peat include mineral components meeting the nutritional requirements of winter wheat. In order to fully satisfy the plant's nutritional requirements, the fertilizer compositions were supplemented with microelements. The bioassays have confirmed the effectiveness of this fertilization and excluded any toxicity of the composted turkey droppings for the proposed fertilizer composition and rates. A similar research has been carried out for other plants used in arable farming, gardening and floriculture.

\section{LITERATURE CITED}

(1) Fotyma M., Pańczyszyn T., Pietruch C.: A decision suport system for sustainable nutrient management on farm level, Nawozy i nawożenie, 2001, 2, 7 - 26.

(2) Barker J. C., Hodges S. C., Walls F. R.: Livestock manure production rates and nutrient content, North Caroliana Agricultural Chemicals Manual, 2002.

(3) Smolińska T.: Surowce odpadowe przemysłu drobiarskiego oraz ich zagospodarowanie, Odpady specjalne, Wyd. AR Wrocław, 1997.

(4) PN-Z-15011-2:2001 - Metoda oznaczania pH w kompostach.

(5) PN-88/R-04013 - Oznaczanie powietrznie suchej i suchej masy.

(6) PN -Z-15011-2:2001 - Oznaczanie zawartości węgla organicznego w kompostach metodą Tiurina.

(7) PN-91/C-87030/18 - Oznaczanie całkowitej zawartości potasu metodą miareczkową z czterofenyloboranem sodu.
(8) PN-Z-15011-3:2001 - Oznaczanie zawartości fosforu metoda kolorymetryczną.

(9) PN-92/C-87030/19 - Oznaczanie wapnia i magnezu w nawozach.

(10) PN-93/C-87085 - Oznaczanie zawartości azotu całkowitego metodac destylacyjna.

(11) PN-ISO 7408 Oznaczanie zawartości azotu amonowego w obecności innych substancji uwalniających amoniak po dodaniu wodorotlenku sodowego.

(12) PN-78/C-87013/04 - Nawozy sztuczne. Badania zawartości związków azotu. Oznaczanie azotu azotanowego.

(13) PN-R-65950:1994 - Materiał siewny. Metody badania nasion.

(14) Koter M.: Chemia rolna, PWN, Warszawa, 1987. 